\title{
TRANSNATIONAL CLASS FORMATION? GLOBALIZATION AND THE CANADIAN CORPORATE NETWORK
}

\author{
Jerome Klassen \\ Center for International Studies \\ Massachusetts Institute of Technology \\ jklassen@mit.edu \\ William K. Carroll \\ Department of Sociology \\ University of Victoria \\ wcarroll@uvic.ca
}

\begin{abstract}
The issue of transnational class formation has figured centrally in recent debates on globalization. These debates revolve around the question of whether or not new patterns of crossborder trade and investment have established global circuits of capital out of which a transnational capitalist class has emerged. This paper takes up the notion of transnational class formation at the point of corporate directorship interlocks. Using Canada as a case study, it maps the changing network of directorship interlocks between leading firms in Canada and the world economy. In particular, the paper examines the role of transnational corporations (TNCs) in the Canadian corporate network; the resilience of a national corporate community; and new patterns of cross-border interlocking amongst transnational firms. Through this empirical mapping, the paper finds a definite link between investment and interlocking shaping the social space of the global corporate elite. Corporations with a transnational base of accumulation tend to participate in transnational interlocking. While national corporate communities have not been transcended, transnational firms increasingly predominate within them, articulating national with transnational elite segments. This new network of firms reconstitutes the corporate power bloc and forms a nascent transnational capitalist class.
\end{abstract}

\section{INTRODUCTION}

The issue of transnational class formation has figured centrally in recent debates on globalization and the world economy. These debates revolve around the question of whether or not new patterns of cross-border trade and investment have established global circuits of capital out of which a transnational capitalist class has emerged. For Stephen Hymer (1979: 262), who first observed this trend in the 1970s, "an international capitalist class is emerging whose interests lie in the world economy as a whole." At the time, Hymer noticed "a strong tendency for the most powerful segments of the capitalist class...to see their future in the further growth of the world market rather than its curtailment." 
With recent trends in economic globalization, many researchers have pushed this theory in new directions. For Michael Hardt and Antonio Negri (2000), globalization has created a new form of Empire, a world economy so interconnected that it overcomes rivalries between states and national blocs of capital: "What used to be conflict or competition among several imperialist powers has in important respects been replaced by the idea of a single power that overdetermines them all, structures them in a unitary way, and treats them under one common notion of right that is decidedly postcolonial and postimperialist" (2000: 9). In a similar vein, Jerry Harris (2005: 329) argues that, "[t]he major dialectic in the present period is the contradiction between the descending form of capitalism organized around the nation-state system and an arising form of accumulation organized in the transnational world order." For this reason, Stephen Gill (2003: 59) views globalization as the political project of a "transnational historic bloc." According to Leslie Sklair (2001), it is leading "corporate executives, globalizing bureaucrats and politicians, globalizing professionals, and consumerist elites," who produce and represent this new class agency.

William Robinson (2004) provides, perhaps, the most systematic version of this theory. In his view, the current period is defined by an epochal shift away from a world economy to a global economy, or from a period in which capitalism was organized nationally and integrated through trade in commodities, to a period in which capitalist production itself is organized globally. New forms of foreign direct investment, outsourcing and subcontracting have unified the world into "a single mode of production" and brought about "the integration of different countries and regions into a new global economy" (2004: 15). According to Robinson, a transnational capitalist class (TCC) has formed in and around these newly globalized circuits of capital. The TCC is "the dominant, or hegemonic, fraction of capital on a world scale" (2004: 21). It manages global production chains and incorporates multiple class agents and formerly national groupings into a new power bloc whose material interests and class unity are located in transnational processes. The TCC is the most dynamic class force in the world economy and the competitive logic it triggers forces local and national capitalists to become more globally integrated as well. The result has been the formation of a new transnational power bloc, which integrates multiple levels of capital and gets organized through global patterns of production and accumulation instead of through national ones. For Robinson (2004: 87), this new power bloc has established a transnational state apparatus (TNS), which includes "transformed and externally integrated national states, together with the supranational economic and political forums," such as the International Monetary Fund, the World Bank, the World Trade Organization, and the United Nations. The TNS institutionalizes "the new class relation between global capital and global labor," and "forge[s] together a new global capitalist historic bloc" (2004: 88).

As one of the more lucid and theoretically grounded versions of the transnational hypothesis, Robinson's work has generated much debate (Bello 2006; Desai 2007; Moore 2002; van der Pijl 2005). For detractors, Robinson's theory has three limitations. First, in terms of methodology, it tends to utilize fixed categories and positive reasoning, and therefore lacks appreciation of dialectical tendencies. Second, it overstates the extent to which globalization has equalized value production and exchange across spaces of the world market. While capital now circulates on a global scale, the world economy is characterized by uneven productive capacities and systematic imbalances between states and regions, which compete for investments, export markets, and profits. Third, the transnational hypothesis tends to mistake the global circulation of capital for the microeconomic integration of capitalist classes. Related to this, it has yet to map a 


\section{JOURNAL OF WORLD-SYSTEMS RESEARCH}

network of cross-border corporate elite connections, which might offer the best empirical evidence of transnational class formation. If such a class is driving the globalization agenda, it should appear, or take concrete shape in directorship interlocks between transnational corporations. For it is precisely at the site of corporate ownership and oversight that capitalist class power emerges and gains political, social and cultural traction (Scott 1997; Carroll 2004; Brownlee 2005).

This paper takes up the notion of transnational class formation at the point of corporate directorship interlocks. Using Canada as a case study, it examines the extent to which globalization is transforming the national corporate community and creating a transnational capitalist class in the form of cross-border interlocking directorates amongst leading firms in Canada and the world economy. Canada is a particularly interesting case for the study of how transnational capitalist class formation intersects with the reproduction (and possible decline) of national corporate communities. For more than three decades, the issue of transnational corporate interlocking has been a mainstay of political economy research in Canada (Carroll 2008). In the 1970s, Naylor (1972) and Clement $(1975,1977)$ argued that American multinationals had fragmented the corporate network in Canada and established a 'continental' structure of corporate power, headquartered in the United States (US) yet supported domestically by a 'comprador' elite. More recently, Panitch and Gindin (2004) utilized this understanding of 'interior' class formation under US hegemony to construct a theory of globalization and American empire. However, this conceptualization of the Canadian corporate elite has often lacked empirical evidence. In the 1980s, the network analysis of Richardson (1982, 1988) and Carroll (1986) revealed a national bloc of 'finance capital' - an integrated network of industrial and financial firms in Canada, independent of US imperialism and expanding autonomously into world markets. Carroll's more recent study $(2004: 81,85)$ of directorship interlocks found that, by 1996, "the entire transnational sector [in Canada] was highly integrated," that Canadian transnational firms interlocked with sub-transnationals, and that finance capital "radiated from Canada in a way that has not disorganized the national network, but has embedded it more extensively in a circuitry of global accumulation." In other words, Carroll documented a globalization of Canadian finance capital, rather than a process of comprador or 'interior' class formation.

Over the past decade, the Canadian economy has maintained a high degree of integration with world markets. Among G7 countries, Canada ranks second in terms of the trade to GDP ratio and the FDI to GDP ratio, and fourth in terms of the UNCTAD index of 'transnationality'. ${ }^{1}$ Since the mid-1990s, Canada has also become a net exporter of capital, as the postwar trend of inward direct investment flows (mostly from US firms) has been superseded by outward direct investments by Canadian corporations (Kentor 2005: 271; Klassen 2009; Burgess 2000). Canada is now home to more than 1,400 multinational corporations, which control approximately 3,700 foreign affiliates. Canada is also home to 72 'world class' corporations, which rank among the top five in their line of business globally. According to Forbes, Canada ranks fifth among countries with corporations listed among the top 2,000 worldwide (see: Klassen 2009). While Canada is highly integrated with the US through the North American Free Trade Agreement,

\footnotetext{
${ }^{1}$ The UNCTAD 'transnationality index' represents an average of FDI inflows as a percentage of gross fixed capital formation, FDI inward stocks as a percentage of GDP, the value added of foreign affiliates as a percentage of GDP, and employment of foreign affiliates as a percentage of total employment. See: UNCTAD (2008). For data on trade and investment in Canada, see OECD (2008: 65).
} 
Canadian firms are increasingly engaged in a wider process of internationalization, especially through foreign direct investments in Europe and Latin America.

These basic indicators of economic globalization make Canada a prime candidate for investigation in terms of transnational class formation. With a highly advanced and globalized economic structure, Canada should exhibit new forms of corporate organization, including directorship interlocks between national and transnational firms, as evident in similar countries such as the Netherlands (Heemskerk 2007). A key question is whether the Canadian corporate community is becoming 'disarticulated' (Scott 1997) as companies based in Canada become more transnational in their investment, ownership, and directorate interlocks.

The purpose of this paper is two-fold: to update the study of class formation in the political economy of Canada, and to offer a concrete case study for testing transnational class theory. In the process, we examine the extent to which transnational class formation is occurring in Canada, and the shifting position of its national corporate community.

We theorize this process by means of two concepts: Domhoff's (2006) 'corporate community' and Sklair's (2001) 'transnational practice'. According to Domhoff, large corporations and corporate directors are drawn together through interlocking directorships, to form a corporate community - a more or less cohesive elite with common goals and shared understandings. The corporate community is a root metaphor for charting capitalist class formation at its higher reaches. In Domhoff's conception, the community is integrated not only through corporate board interlocks, but also through the participation of corporate directors on policy-planning boards and other elite vehicles for building consensus; however, this study restricts itself to corporate interlocks.

Sklair (2001), in theorizing the transnational capitalist class, defines transnational practices as those "that cross state boundaries but do not necessarily originate with state agencies or actors" (Sklair and Robbins 2002: 82). For any given corporation, three such practices are particularly relevant:

i. The firm's foreign direct investments, i.e., its outward reach, via ownership of subsidiaries, into various other countries, representing an exteriorization of its corporate power beyond the domestic scene;

ii. The inward reach of a foreign corporate interest via major shareholding in the firm, i.e., foreign control of the company, representing an interiorization of foreign corporate power into the domestic scene; and:

iii. Directorate interlocking between the firm and large corporations domiciled in other countries, i.e., transnational interlocking.

Although all three practices contribute to transnational class formation, the first and the second carry quite different implications for the meaning of the third. For a company exteriorizing its corporate power through outward investment, transnational interlocks improve the business scan that facilitates effective decision-making beyond familiar locales (Useem 1984). Alternatively, a firm controlled by a foreign-based parent may share directors with the parent, enabling the latter to oversee its operations (this was the case in the mid-1970s network of European and American corporations studied by Fennema and Schijf 1985). As Kentor (2005: 282) suggests, "ownership of a foreign subsidiary transfers some amount of power from the host country to the TNC," with board interlocks providing a conduit of that power. A familiar example is Chrysler Group LLC, 
the re-born version of a firm first established by Walter Chrysler in 1925, and controlled in the US until it merged with German-based Daimler in 1998, at which time its domicile moved to Germany, although US-based capitalists continued to be represented in top management and on the supervisory board (Neubauer et al. 2000). Daimler eventually cashed out its American investment to private equity firm Cerberus and severed its ties to Chrysler. In 2009, in the wake of the financial crisis and on the verge of bankruptcy, Chrysler was bailed out by American and Canadian governments and a significant stake was acquired by Fiat of Italy, which currently appoints three of nine directors as well as the CEO.

These microeconomic scenarios bear upon the fate of national corporate communities and their location within the world system. For a corporate community whose leading companies fall under foreign control, rising incidences of transnational interlocking may indicate a 'hollowing out' (Arthurs 1999) - a compositional shift toward an 'interior bourgeoisie' that represents, on the domestic scene, the corporate power of foreign-based interests (Poulantzas 1978: 72). As the accumulation base for the national corporate community shrinks, transnational interlocks reinforce a dynamic of compradorization (Clement 1977) that further erodes that national corporate community's competitive position within the world system. The result can be a "harvest of lengthening dependency," which Levitt (1970: 116) predicted for Canada in the wake of the postwar expansion of US corporate capital.

Alternatively, a corporate community that expands into other countries and establishes transnational board interlocks develops its base of accumulation beyond the domestic market, and exteriorizes the reach of its corporate power.

In reality, both these tendencies are present in any national locale. The key empirical issue in assessing the impact of globalization on a corporate community is to what extent one or the other predominates. An additional consideration is how transnational practices of exteriorization, interiorization and directorate interlocking articulate with the domestic corporate network - the center-of-gravity for a national corporate community. Schematically, several combinations of tendencies in the corporate community's accumulation base and in its board interlocks are possible, five of which are delineated in Table 1. 'A', which might be deemed a null hypothesis, represents a national corporate community unaffected by the transnational practices we have discussed. ' $\mathrm{B}$ ' shows a corporate community exteriorizing its accumulation base and establishing transnational interlocks while maintaining a strong national network. ' $\mathrm{C}$ ' depicts the same expansion of foreign investment and of transnational interlocks, in step with the atrophy of the national network. In 'D', transnationalization takes an interiorizing form, shrinking the corporate community's accumulation base and eroding its national network, as proliferating transnational interlocks trace the power of foreign parents over domestic subsidiaries. In ' $E$ ' the corporate community expands its accumulation base and its connections abroad even as foreign interests penetrate and the national network declines. This is the scenario of transnationalization and national disarticulation predicted by Robinson (2004) and also Scott (1997). Finally, in 'F' all three transnational practices occur yet the national network remains a robust source of cohesion for the corporate community.

Below, we analyze recent tendencies in Canada, in view of these scenarios, and draw tentative conclusions on the social organization of corporate elite in the present period of neoliberal globalization. 
TRANSNATIONAL CLASS FORMATION? 384

Table 1. Scenarios of Transnationalization for National Corporate Communities

Accumulation Base

Scenario

A

B

$\mathrm{C}$

$\mathrm{D}$

E

$\mathrm{F}$
Interiorization
Exteriorization

Exteriorization $\quad \begin{gathered}\text { Transnational } \\ \text { interlocking }\end{gathered}$

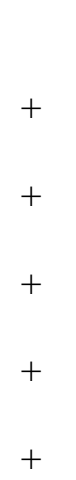

National interlocking

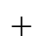

$+$

$+$

\section{METHOD AND FINDINGS}

To represent the national corporate community, we use Carroll's (2004) data for yearend 1996 as a starting point and replicate his methods for defining and analyzing the corporate network in 2006. Over this ten-year period, we examine the changing composition and interlock network of a 'C250' set of firms headquartered in Canada, consisting of the largest 200 non-financial corporations (ranked by total revenue) and the largest 50 financial institutions (ranked by total assets). ${ }^{2}$ To track relations between Canada's corporate community and the world's largest nonCanadian corporations, we examine the boards of a 'G500' set of firms, representing the largest 500 companies globally, consisting of the 400 largest non-financials (ranked by revenue) and the 100 largest financials (ranked by assets). ${ }^{3} \mathrm{We}$ explain how we operationalize our variables as we introduce successive phases of the analysis.

\footnotetext{
${ }^{2}$ In compiling the C250, the main source for data on firm size was the Financial Post 500 listings, published in July 1997 and 2007. To qualify for the C250, a corporation could not be wholly owned by another Canadian corporation. However, wholly owned Canadian subsidiaries of foreign TNCs (e.g., Walmart Canada, Honda Canada, Ford Motor Co. of Canada, Toyota Canada) were included in the C250 if they met the size criteria. Data on board composition was sourced from the annual reports of the corporations, available at company websites or at the Mergent Online database. To maintain consistency throughout the analysis, we restrict ourselves to companies for which we were able to obtain complete data on firm size and board composition.

${ }^{3}$ Data for G500 companies are from Carroll's (2009) study. In compiling each G500, Carroll employed the same criteria as ours for the C250 but doubled the $n$, selecting the 400 largest non-financials (ranked by revenue) and the 100 largest financials (ranked by assets). To qualify for the G500, a corporation could not be wholly owned by another corporation. Names of directors of G500 corporations were taken mainly from
} 


\section{A. The Scope of Transnationalization in Canada}

We first report on changes to the accumulation base for leading Canadian firms, as evident in three measures: the degree of transnationality in the C250, the geographic spread of C250 subsidiaries ${ }^{4}$, and the country of control (Canadian controlled vs. foreign-controlled) of C250 firms. ${ }^{5}$ The first two of these are measures of exteriorization - the outward reach of corporate power from Canada. The third is an indicator of interiorization - the inward reach of corporate power into Canada, via foreign direct investment. To operationalize exteriorization, we follow Niosi's (1985) typology of transnationality and distinguish four categories: (1) TNCs (incorporated in Canada and holding subsidiaries in four or more other countries - the most exteriorized firms), (2) near-TNCs (owning subsidiaries in fewer than four countries, including at least one country other than the US), (3) continentalized firms (operating subsidiaries only in the US), and (4) nationally bound firms (having no foreign subsidiaries). ${ }^{6}$

\section{Table 2. Transnationality of C250 Corporations}

\begin{tabular}{llclc} 
Transnationality & \multicolumn{2}{c}{ N of firms } & \multicolumn{2}{c}{ Mean revenue (\$Bill Can) } \\
& 1996 & 2006 & 1996 & 2006 \\
Nationally bound & 112 & 115 & 2.35 & 3.41 \\
Continental (US subsidiaries only) & 38 & 40 & 2.34 & 4.01 \\
Near transnational & 48 & 36 & 3.42 & 6.42 \\
TNC (subsidiaries in 4+ countries) & 50 & 56 & 5.77 & 10.03 \\
Total & 248 & 247 & 3.25 & 5.45
\end{tabular}

corporate annual reports. See Carroll (2010) for details. The Canada-based corporations that qualified for both the C250 and G500 (nine in 1996, 15 in 2006) are analyzed as members of the C250, not G500; i.e., the G500 contains only companies that, from a Canadian standpoint, are foreign-based.

${ }^{4}$ Data on foreign subsidiaries of C250 firms were gleaned from Who Owns Whom (Dunn and Bradstreet, 1997 and 2007 editions), whose listings enable counts of companies majority-owned by a given firm, and by all subsidiaries of that firm, i.e., the total number of subsidiaries (direct and indirect) for each firm. The domicile of every parent and subsidiary is indicated, enabling the assignment for each C250 firm of its subsidiaries to specific national domiciles. Since Who Owns Who displays intercorporate ownership relations as nested hierarchies, we were able to assess each firm's subsidiaries (categorized by domicile of the subsidiary) by examining companies listed underneath it in the hierarchy of ownership. This applied not only to firms that were ultimate parents but to Canadian subsidiaries of foreign-based companies.

${ }^{5}$ Data on country of control were taken from the Financial Post 500 listings, supplemented where necessary by the Financial Post InfoMart database (http://www.fpinfomart.ca/). A company is categorized under foreign control if 50 percent or more of its share capital is held outside Canada or if the largest block of shares comprising at least $20 \%$ of share capital is owned by a single foreign investor. Canadian controlled companies are firms that do not meet these thresholds for foreign control. In practice, foreign control nearly always involves majority-ownership of a corporation's share capital.

${ }^{6}$ Counting subsidiaries implicitly weights each one equally, with the result that a firm with five foreign subsidiaries, each with revenues of $\$ 20$ million appears as five times more transnationalized than one with a single foreign subsidiary whose revenues amount to $\$ 100,000$. This measure of transnationality is not nearly as sensitive as the UNCTAD 'transnationality index', yet it is the best we can do with available data. 
In the decade following 1996, we find an increase in the number of fully-fledged Canadian transnationals, but a decrease in the complement of near-transnationals (Table 2). There is no general tendency for $\mathrm{C} 250$ firms to become more 'transnationalized'; rather, to some extent, the C250 becomes more polarized: by 2007 it contains a larger complement of TNCs, but also a larger complement of nationally bound or continentally oriented firms. This polarization in transnationality has occurred in conjunction with a polarization in firm size within the C250. Typically, it is only very large firms that become TNCs, as they outgrow their home market, and this is certainly the case in Canada. In 1996, Canadian TNCs had revenues on average twice as large as nationally bound C250 firms. In the decade under study, TNCs and near-TNCs grew much more quickly than other C250 firms, so that by 2006 the four categories of transnationality accounted for 14.4 per cent of the variance in revenue, compared to 10.0 per cent in $1996 .{ }^{7} \mathrm{We}$ therefore find evidence of differential rates of accumulation between faster-growing TNCs and slower-growing, nationally bound firms in the C250.

Another basic indicator of transnationalization is the total number of foreign subsidiaries owned by C250 companies. Although this value dipped slightly over the decade under study (from 2,523 to 2,509), closer inspection showed the overall shift to be attributable to a sharp decrease in foreign subsidiary listings in known tax havens (from 243 subsidiaries in 1996 to 50 in 2006). The significance of this decrease is unknown. However, such subsidiaries are, typically, more strategic devices for sheltering income than they are sites for accumulating capital through production, circulation and finance. Leaving aside the tax havens, the inter-continental spread of C250 foreign subsidiaries is shown in Table 3.

\section{Table 3. Number of C250 Foreign Subsidiaries, Categorized by Host Region}

$\begin{array}{llll}\text { Domicile of subsidiary } & 1996 & 2006 & \text { \% change } \\ \text { US } & 1013 & 884 & -12.7 \\ \text { Europe } & 771 & 1138 & +47.6 \\ \text { Latin America } & 230 & 152 & -33.9 \\ \text { Asia-Pacific } & 240 & 270 & +12.5 \\ \text { Africa } & 26 & 15 & -42.3 \\ \text { Total } & 2280 & 2459 & +7.9\end{array}$

Across the decade, the number of (non-tax-haven) foreign subsidiaries of C250 firms grows by approximately eight percent, as Europe displaces the US as the main host region. Canadian foreign subsidiaries also proliferate in the Asia-Pacific region, but their numbers diminish in Latin America and Africa.

Although on average each corporation in the C250 owns 10 foreign subsidiaries, the distribution of ownership is highly skewed. Overwhelmingly, ownership of foreign subsidiaries is concentrated among the Canadian transnationals. Our database shows that, in 1996, 79.9 per cent all C250 foreign subsidiaries were owned by the 50 Canadian TNCs; in 2006, 56 TNCs owned

\footnotetext{
7 These proportions are the values of Eta-squared based on one-way analyses of variance, with transnationality as the independent variable and revenue as the dependent variable. In this context, Etasquared indicates the proportion of the total variance in revenue that is attributable to between-group differences in transnationality.
} 
84.7 per cent of all C250 foreign subsidiaries. Among foreign subsidiaries domiciled outside the US, the concentration of transnational investment was even more pronounced. Canadian TNCs owned 92.0 per cent of such firms in 1996 and 93.7 per cent in 2006. Moreover, subtransnationals active in foreign direct investment tended to restrict their investments to subsidiaries in the US or UK. Broadly, the pattern is for Canadian TNCs to own subsidiaries in the US and UK, plus several other countries, often in Europe but also in Latin America and the Asia-Pacific zone. Sub-transnationals that own foreign subsidiaries are typically restricted to direct investments in the US and, secondarily, UK. These countries, culturally similar to (anglo-) Canada and (particularly in the case of the US) spatially proximate, may serve as staging grounds for further transnationalization by Canadian corporations.

\section{Table 4. Transnationality and National Locus of Control}

\begin{tabular}{|c|c|c|c|c|c|c|c|c|c|c|}
\hline Country & Natio & & Conti & ntal & Near- & & TNC & & Total & \\
\hline $\begin{array}{l}\text { of } \\
\text { control }\end{array}$ & 1996 & 2006 & 1996 & 2006 & 1996 & 2006 & 1996 & 2006 & 1996 & 2006 \\
\hline Canada & 54.5 & 67.0 & 89.5 & 87.5 & 72.5 & 86.1 & 94.0 & 91.1 & 71.4 & 78.5 \\
\hline US & 27.7 & 13.0 & 5.3 & 5.0 & 14.6 & 13.9 & 6.0 & 3.6 & 17.3 & 9.7 \\
\hline Europe & 10.7 & 14.8 & 2.6 & 7.5 & 4.2 & & & 1.8 & 6.0 & 8.5 \\
\hline $\begin{array}{l}\text { Asia- } \\
\text { Pacific }\end{array}$ & 7.1 & 5.2 & & & 8.4 & & & 1.8 & 4.8 & 2.8 \\
\hline Other & & & 2.6 & & & & & 1.8 & 0.4 & 0.4 \\
\hline Total \% & 100 & 100 & 100 & 100 & 100 & 100 & 100 & 100 & 100 & 100 \\
\hline Total \# & 112 & 115 & 38 & 40 & 48 & 36 & 50 & 56 & 248 & 247 \\
\hline
\end{tabular}

As Table 4 demonstrates, there is an important inverse relationship between exteriorization and interiorization, i.e., between a firm's degree of transnationality and whether it is controlled by foreign interests. ${ }^{8}$ Canadian TNCs are almost all controlled domestically, and the slight rise in foreign control of TNCs (from 6.0\% to 8.9\%) coincides with a decline in US control. At the other end of the continuum, foreign control is most prevalent among nationally bound companies (i.e., firms that have not exteriorized their accumulation bases), one third of which were foreign controlled in 2006. Overall, most C250 firms are controlled by Canadian interests (whether capitalists, the state, or in a few cases, cooperatives), and this trend strengthens over the decade, as the number of $\mathrm{C} 250$ firms controlled outside Canada drops from $71(28.5 \%)$ to $53(21.2 \%)$. It is particularly among the near-TNCs and the nationally bound firms that foreign control drops. For the latter, US control plummets, but European control increases slightly. The relationship in Table 4 implies that when we speak of Canadian transnationals we are in nearly all cases speaking of very large, Canadian-controlled corporations, not of Canadian branch plants that act as 'go-betweens' in managing the foreign investments of their parents (Clement 1977). In contrast, nationally bound firms are not only smaller; a good many are foreign-owned subsidiaries that interiorize foreign-based interests.

To summarize, our findings on the transnationality of C250 corporations, the geographic spread of their subsidiaries, and the locus of national control indicate key transformations in the

${ }^{8}$ The contingency coefficient for the 1996 data in Table 4 is 0.359 ; for the 2006 data, it is 0.298 . 
accumulation base of corporate Canada. First, we observe a polarization in the C250 between TNCs, which are leading sites of capital accumulation, and non-TNCs, which are less dynamic in their rates of growth. Second, we find evidence of a more diverse geographic spread of subsidiary locations, as C250 firms expand rapidly beyond North America into Europe, Asia, and other regions of the world economy. Finally, we note a decline of foreign control in the C250, a transnational diversification of that control, and a tendency for foreign control to be concentrated among nationally bound firms. These transformations indicate a complex process of transnationalization in the accumulation base of the $\mathrm{C} 250$. Both interiorization and exteriorization are evident, but they apply to different C250 firms, and the overall trends favour externalization and a diversification of foreign domiciles - both as destinations for Canadian direct investment and as loci of foreign control.

\section{B. Transnationality and Interlocking Directorates: Changes in the Corporate Community}

How do these changes in the accumulation base bear upon the network of interlocking directorates, and what are the implications for the national corporate community? To answer this question we first need to distinguish between two kinds of corporate interlocking. National interlocking occurs when two companies based in the same country share one or more directors; its effect is to help bond corporate directors into a national corporate community. In an entirely introverted corporate community (Scenario A in Table 1) all ties would bond members to each other. Transnational interlocking occurs when two firms domiciled in different countries share one or more directors, thus bridging across national borders (Carroll 2010). A major shift from national to transnational interlocking could disarticulate the relatively introverted corporate communities that were a legacy of $20^{\text {th }}$ century organized capitalism (Scott 1997; as in scenarios $\mathrm{C}, \mathrm{D}$, and $\mathrm{E}$ in Table 1).

Recent scholarship has established an uneven shift towards transnational interlocking among the world's largest corporations (Kentor and Jang 2004; Carroll 2009). However, the increase in transnational interlocking has not supplanted national corporate networks, and much of the growth in transnational interlocking reflects the consolidation of a pan-European corporate community (Carroll 2009). It is well to note also that the decade between 1996 and 2006 marked widespread adoption of American-style corporate governance practices, which tended to decrease the size of corporate boards and the extent of directorate interlocking, in pursuit of efficiencies that enhance shareholder value and consolidate both operational and strategic control in parent head offices (Carroll 2010).

In the case of Canada, Carroll (2004) found that between 1976 and 1996, the transnationalization of Canadian corporations did not lead to a weakening of the elite network. In both years, TNCs were the most central firms in the network, and their boards were densely interlocked with the directorates of Canadian-controlled sub-TNCs. The tendency was for the network to become "centred more around a core of transnational banks and corporations, controlled by capitalists based in Canada" (p. 85), matching our scenario B and pointing up "the resilience of the national factor in elite organization" (p. 209). More recently, Carroll and Klassen (2010) discovered for 2006 the reproduction of a national corporate community, against the tendency to 'hollowing out' associated with foreign direct investment and cross-border mergers and acquisitions. 
What, then, are the most recent developments in the network of directorship interlocks, both within Canada and between Canada and the world economy? How has the dialectic of accumulation and class formation materialized over the decade? Is a transnational capitalist class in the making?

Figure 1. Mean Degree of National and Transnational Interlocking for Categories of Transnationality in the C250, 1996 and 2006

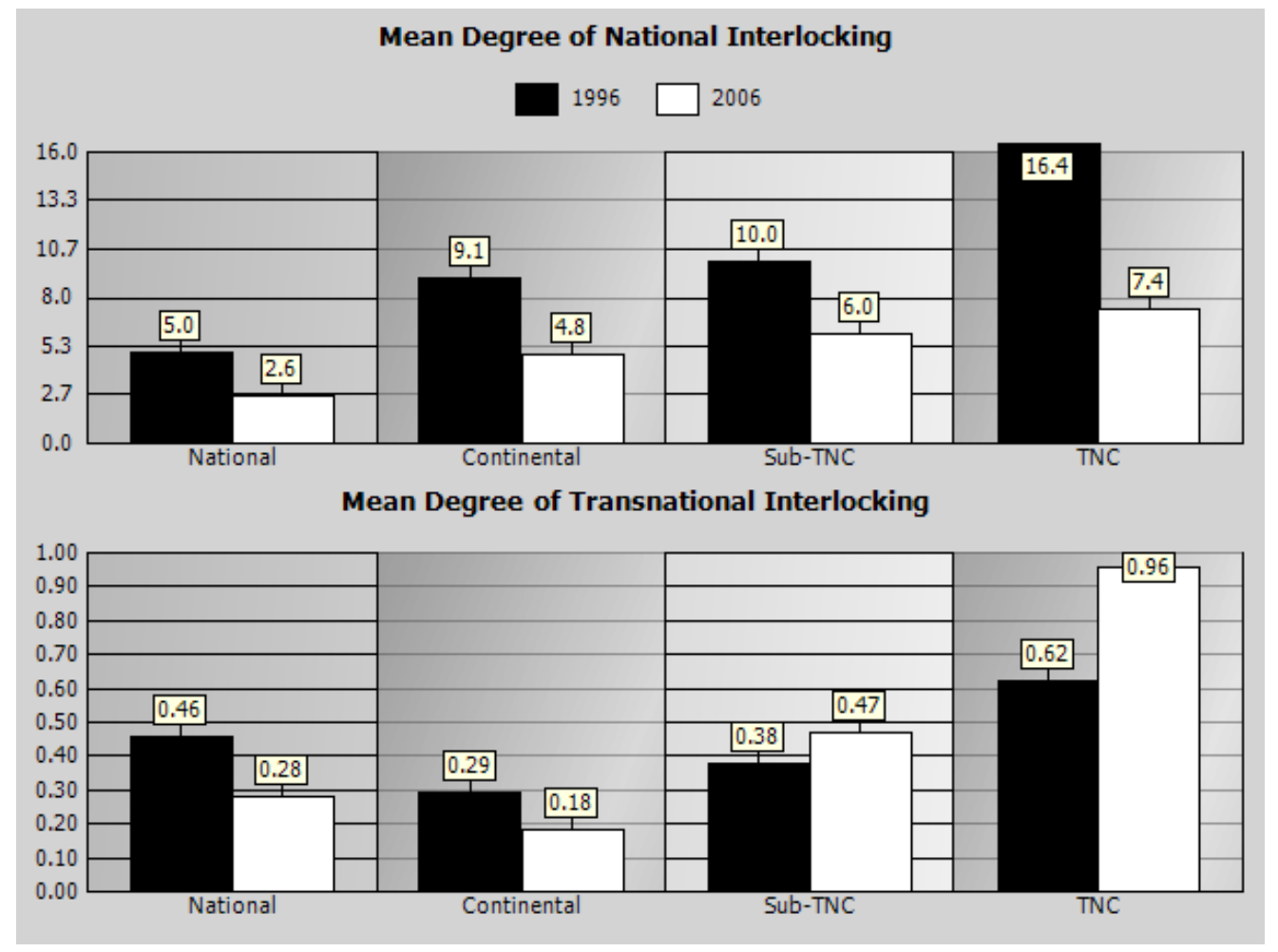

Figure 1 charts levels of interlocking (mean degree) - both national (top panel) and transnational (bottom) - at 1996 and 2006, for C250 corporations grouped by transnationality. The top panel confirms a continuing decline after 1996 in the degree of national interlocking (i.e., the number of other C250 firms with which a company shares one or more directors). Over all subcategories of C250 firms, mean national degree fell from 8.9 to 4.6; i.e., the number of other C250 corporations with which a company shares one or more directors decreased by nearly half. Comparing top and bottom panels, the vast difference between degree of national and transnational interlocking, across all categories of transnationality, indicates that the corporate network remains nationally centred. Over all subcategories, mean transnational degree (i.e., the number of non-Canadian G500 corporations with which a company shares one or more directors) remained constant at 0.45 . However, this apparent stasis belies a definite polarization as TNCs become more engaged in transnational interlocking while nationally-bound and continentally invested firms become less engaged in transnational interlocking. In 1996, the four categories of transnationality in Figure 1 account for a trivial 0.5 per cent of the variance in transnational degree, but a decade later the 
same between-group differences account for 7.0 per cent of the variance. Still, by 2006 Canadian TNCs continue to show the highest mean degree of interlocking with $\mathrm{C} 250$ firms, and the between-group differences in national degree are sharper than in transnational degree. ${ }^{9}$ These findings suggest that Canadian TNCs (nearly all of which are domestically controlled) continue to match our scenario B: transnationalized in their investments and interlocks, they remain extensively networked with other Canadian corporations.

How does the phenomenon of interiorization figure in the network? Overall, as Figure 2 shows, foreign-controlled firms began the decade substantially less interlocked with other C250 corporations than did Canadian-controlled companies. In 1996 the mean national degree for Canadian-controlled firms was 10.4; for foreign controlled firms it was 5.0. Although the grand mean for all C250 companies fell from 8.9 to 4.6, it was especially US-controlled companies that withdrew from the network of national interlocks after 1996. The four categories of country of control in Figure 2 account for 8.1 per cent of variance in national degree in 1996 and 9.9 per cent in 2006 - the increase indicating a recent sharpening of the tendency for companies controlled in Canada to bond with other $\mathrm{C} 250$ corporations. ${ }^{10}$

We saw in Table 4 that foreign control of C250 firms has recently decreased, but that it persists to some degree among firms lacking any foreign subsidiaries (matching the classic 'branch plant' pattern of corporate control and management - Levitt 1970); indeed, such nationally bound firms account for nearly three-quarters of all foreign controlled C250 companies, in both years. Figure 3 focuses only on the nationally bound subgroup. We find that the mean degree of national interlocking for Canadian controlled firms fell only mildly after 1996, while for (nationally bound) firms under foreign control it plummeted. Thus, in the same decade that Canadian TNCs increased their participation in the transnational network, foreign controlled branch plants became more detached from the national network.

In effect, over the decade spanning the turn of the century, the network became more 'Canadian' (less interiorized) in its national, bonding aspect yet more linked into the global corporate elite (more exteriorized), particularly through Canadian TNCs controlled domestically. ${ }^{11}$

Although Figure 1 shows that Canadian TNCs tend to interlock extensively with C250 companies, this does not tell us whether their interlocks lead simply to other TNCs (potentially constituting a transnationalized network disarticulated from the rest of the Canadian corporate community) or to the full range of large Canadian firms. By charting the density of interlocking

\footnotetext{
${ }^{9}$ The Eta-squared values, with national degree as the criterion, are 0.250 in 1996 and 0.199 in 2006.

${ }^{10}$ Not evident in Figures 1 and 2 are three kinds of statistically deviant cases. (1) In 1996 the category of near TNCs controlled in Europe had two members. One of them - Shell Canada - was interlocked with two non-Canadian G500 firms; thus the mean degree for this very small category was 1.0. (2) In contrast, in the same year, the nationally-bound firms controlled by interests outside the North Atlantic made up a more substantial category of eight firms (see Table 4), all subsidiaries of Japanese parents, and in several cases linked to multiple members of Japan-based corporate sets - accounting for the unusually high mean transnational degree of 1.6 (on corporate sets in Japan see Scott 1997: 181-95). (3) By 2006, three firms with continental investments, each controlled in Europe, show elevated national degree: Shell Canada with 13 such interlocks, Imperial Tobacco Canada with 4, St Lawrence Cement with 6.

${ }^{11}$ In both 1996 and 2006, Canadian TNCs under domestic control engaged in far more transnational interlocking than the few TNCs under foreign control. In 2006, mean degrees were 1.04 for Canadiancontrolled TNCs and 0.20 for foreign-controlled TNCs.
} 
within and between segments of the network, we can appraise these scenarios. Density, the number of actual interlocks divided by the maximum possible number of interlocks (i.e., if all pairs of firms were directly linked), indicates the probability that a pair of companies is interlocked. In 1996, the overall density for the C250 was 0.0721; in 2006 it was 0.0374.

Figure 2. Mean Degree of National and Transnational Interlocking for Categories of Country of Control in the C250, 1996 and 2006

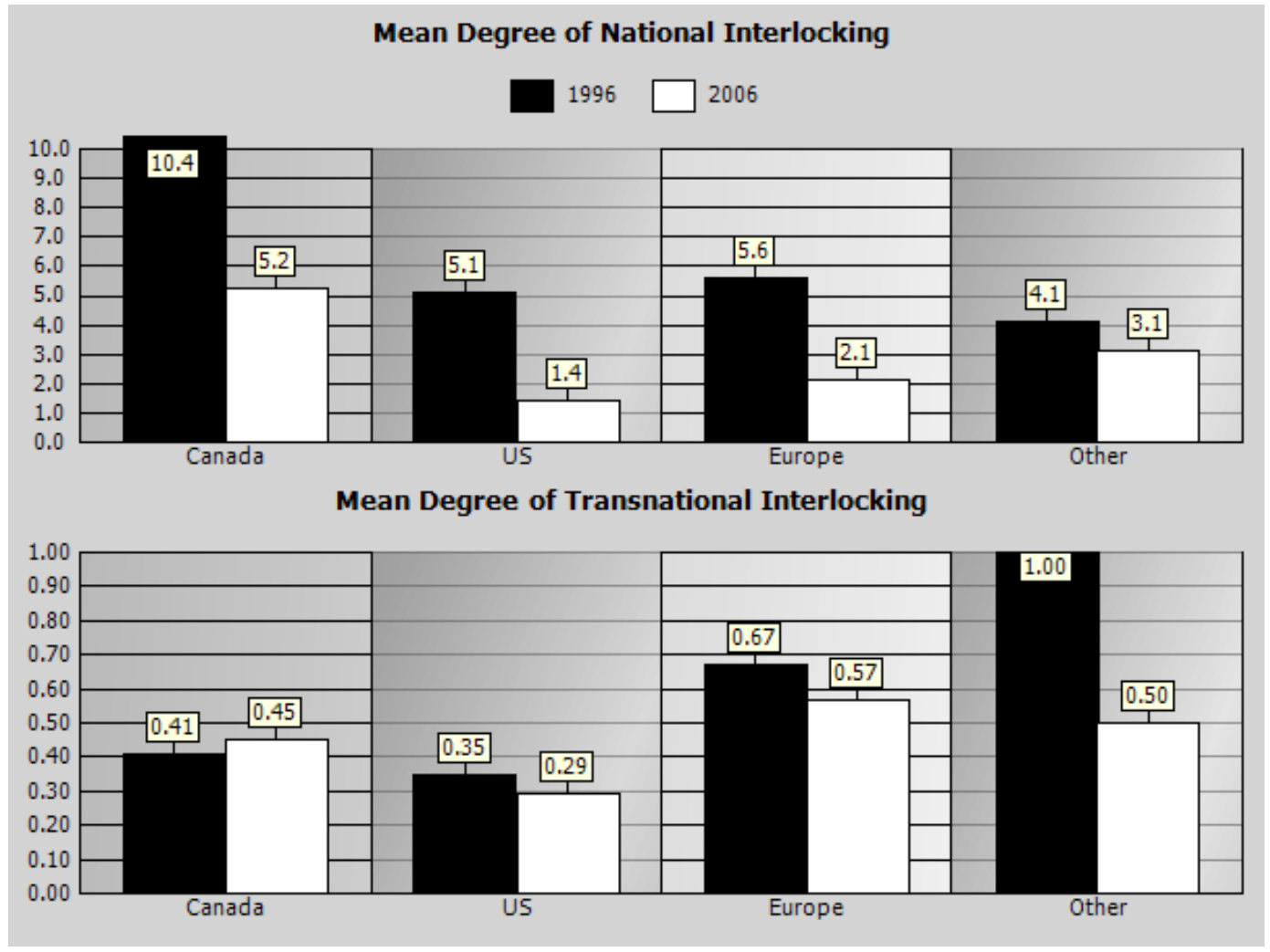

Using these as benchmarks, we see in Table 5 that in both years, the network is centralized around the TNCs, which interlock extensively with each other (particularly in 1996) and less extensively with near-TNCs and continental firms. In sharp contrast, nationally bound firms (comprising nearly half of the C250) rarely interlock with each other, and after 1996, do not share directors to any appreciable extent with the more transnationalized companies. In this sense, the national network not only becomes sparser across the decade, it becomes primarily a configuration of the boards of corporations whose investments extend beyond Canadian territory.

As for transnational, bridging interlocks, these also become increasingly the province of TNCs. Whereas in 1996 there was no tendency for transnationality in direct investments to be associated with transnational interlocking (ANOVA-based Eta-squared=.005), by 2006 our database shows that transnationality explained 7.0 per cent of the variance in transnational degree. Among the 30 corporations which ranked as TNCs in both 1996 and 2006, the growth in transnational interlocking was particularly notable. Already in 1996, the mean degree of 
transnational interlocking for these 30 , at 0.73 , was nearly double the grand mean. By 2006, at 1.33 , it was triple the grand mean: i.e., the longstanding TNCs had three times the number of transnational interlocks as did C250 corporations overall. It is particularly among the wellestablished, top-tier Canadian TNCs that transnational interlocking became fairly common after the mid-1990s.

Figure 3. Mean Degree of National Interlocking for Categories of Country of Control, Nationally-Bound Companies, 1996 and 2006

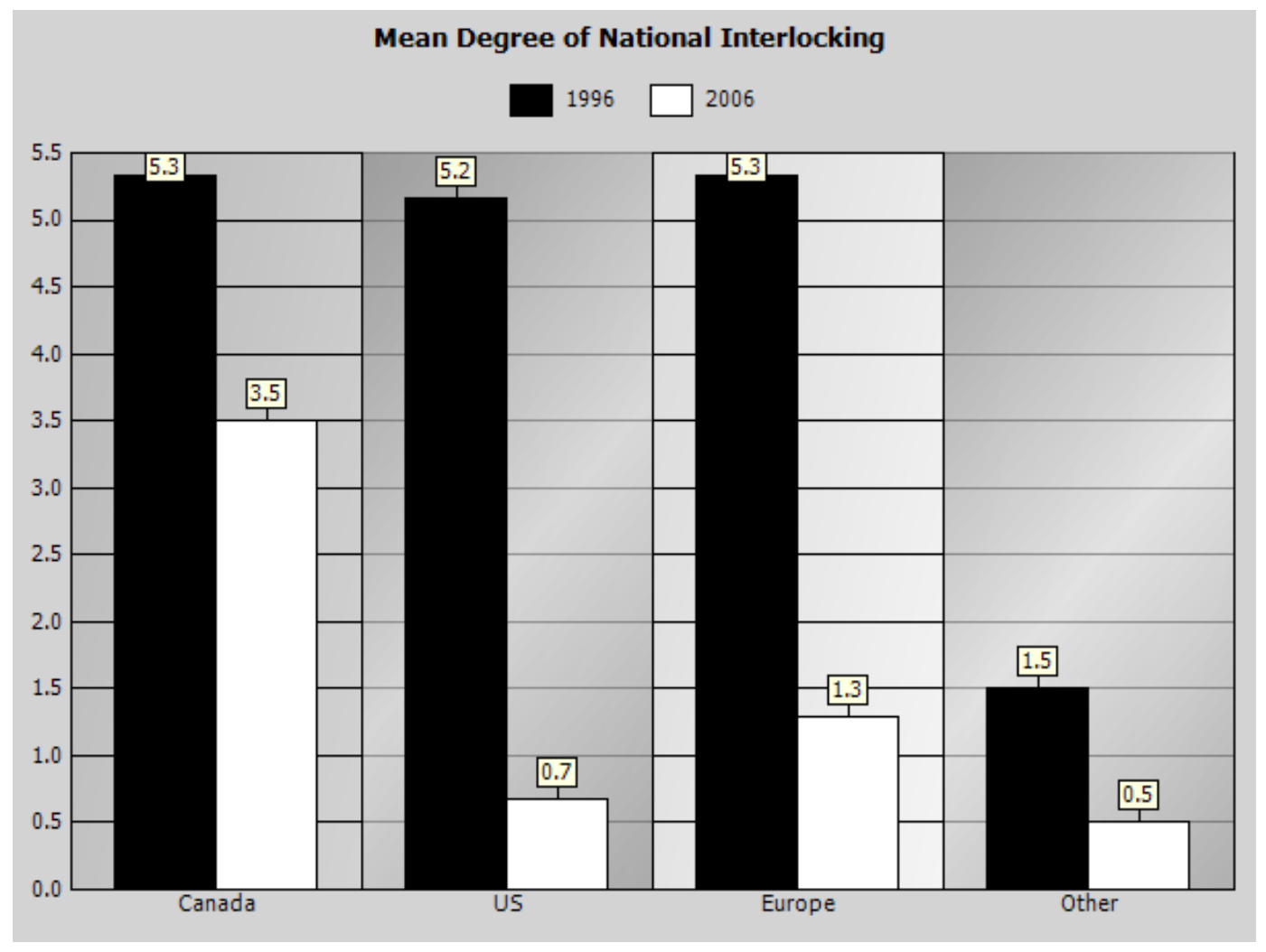

Instead of comparing the positions of firms within the network, another way of mapping the relation between transnational investment and transnational interlocking is to examine the distribution of the interlocks, across categories of transnationality. How much of the interlocking between C250 firms and non-Canadian G500 firms involves Canadian TNCs, in comparison with, say, nationally bound companies? In 1996 there was a total of 111 interlocks between C250 firms and non-Canadian G500 firms; in 2006 the total number of transnational interlocks was 110. As Figure 4 shows, in 1996, 31 transnational interlocks were carried by Canadian TNCs, comprising slightly more than a quarter of the total. A decade on, nearly half of all transnational interlocks 
link G500 boards with the boards of Canada's 56 major TNCs. ${ }^{12}$ Besides the increasing role of Canadian TNCs in transnational interlocking, the other major shift evident in Figure 4 is the sharp drop in transnational interlocks that involve, on the Canadian side of the relation, firms with operations only in Canada. In effect, over the decade transnational interlocking became much less dispersed among many firms bound within Canada, and more concentrated within a relatively compact group of TNCs, even as the TNCs continued to claim a constant proportion of the bonding ties that knit together a national corporate community.

\section{Table 5. Sectoral Densities Within and Between Categories of Transnationality}

\begin{tabular}{|c|c|c|c|c|}
\hline \multicolumn{5}{|c|}{ A. 1996} \\
\hline & Nat'l & Cont'1 & Near-TNC & TNC \\
\hline Nationally bc & 0.013 & 0.025 & 0.027 & 0.036 \\
\hline Continental & 0.025 & 0.047 & 0.039 & 0.066 \\
\hline Near-TNC & 0.027 & 0.039 & 0.045 & 0.079 \\
\hline TNC & 0.036 & 0.066 & 0.079 & 0.134 \\
\hline \multicolumn{5}{|c|}{ B. 2006} \\
\hline & Nat'l & Cont'1 & Near-TNC & TNC \\
\hline Nati & 0.008 & 0.012 & 0.016 & 0.012 \\
\hline Continental & 0.012 & 0.015 & 0.025 & 0.034 \\
\hline Near-TNC & 0.016 & 0.025 & 0.027 & 0.040 \\
\hline TNC & 0.012 & 0.034 & 0.040 & 0.056 \\
\hline
\end{tabular}

Recalling our earlier analysis, which showed relatively high rates of foreign control among nationally bound corporations, and flagging rates of participation in the national network by nationally bound firms under foreign control (Figure 3), it is worthwhile to unpack the nationally bound category further, now on the issue of participation in the transnational network. When we do so, we find that, in 1996, most of the transnational interlocks carried by nationally bound firms directly reflected interiorizing, transnational parent-subsidiary relations. Of the 51 transnational interlocks carried by nationally bound firms, 35 were carried by foreign controlled companies, mostly connecting them back to their parents. ${ }^{13}$

By 2006, as we have seen, nationally bound firms play a more circumscribed role in transnational interlocking, carrying a total of 32 such ties. Again, there is a tendency for these interlocks to be part and parcel of interiorizing relations: 18 of the 32 involve Canadian

\footnotetext{
${ }^{12}$ By way of comparison, the proportion of all domestic interlocks involving Canadian TNCs held steady through the decade ( 820 of 2,204 domestic interlocks in 1996; 413 of 1,128 domestic interlocks in 2006, comprising 36.6 per cent of all domestic ties).

${ }^{13}$ Included among these companies were the Canadian subsidiaries of Toyota, Nissan, Honda, Mitsubishi, Mitsui, Itochu, Bank of Tokyo (all based in Japan), McDonalds, Sears Robuck, Costco, Gulf's parent, A\&P's parent, Textron's parent, Weyerhaeuser (all based in the US), LaFarge, Societe Generale (based in France), and HSBC (based in Britain).
} 
subsidiaries of foreign-based transnationals. ${ }^{14}$ These interlocks are generated through parentsubsidiary relations that reach into the Canadian economic space.

Figure 4. Transnational Interlocks Classified by Transnationality, 1996 and 2006

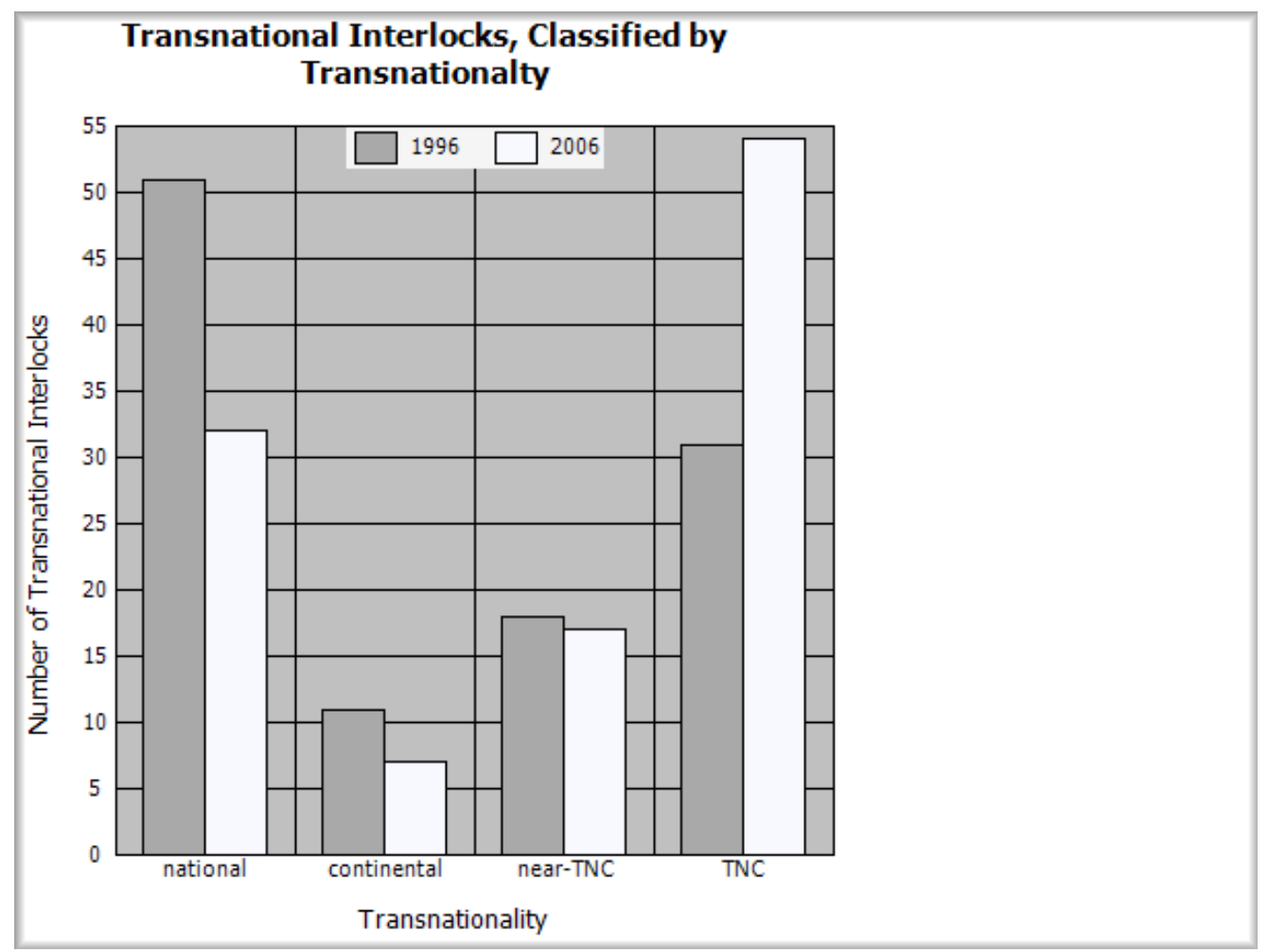

The bimodal distribution of transnational interlocks across the four categories of transnationalization in Figure 4 reflects the double-sided character of corporate organization in an era of extensive multinational cross-penetration of investment among developed capitalist economies. The two categories that account for most transnational interlocks reflect complementary insertions into global capitalism. Comparing 1996 with 2006, we find a shift from transnational interlocking of the interiorizing sort to transnational interlocking of the exteriorizing sort. In the interiorizing mode, as explained earlier, board interlocks extend from foreign parents to Canadian subsidiaries, expressing a penetration of corporate power from without. Across the decade, the number of transnational interlocks involving foreign-controlled C250 firms decreases

\footnotetext{
${ }^{14}$ By 2006, these firms tend to link across the Atlantic, to European parents, rather than continentally to American or across the Pacific to Japanese parent companies. Canadian subsidiaries with transnational interlocks to their G500 parents in 2006 include GlaxoSmithKline, Standard Life, Wolsley Insurance and HSBC (all controlled in Britain), AXA Canada and Aviva Canada (controlled in France), ING Bank and TransAmerica (controlled in the Netherlands), Sears Canada, Apache Canada and Tim Hortons (controlled in the US), Sony Canada and Honda Canada (controlled in Japan) and Husky Energy (controlled in Hong Kong).
} 
nearly by half. The decline of such interlocks reflects both the decreasing complement of foreigncontrolled firms in the $\mathrm{C} 250$ and the waning tendency for foreign-controlled branch plants to maintain directoral ties to their parents - in part due to a transformation of the organizational structures of TNCs (Carroll and Klassen 2010).

In contrast, exteriorizing transnational interlocking occurs as Canadian TNCs (controlled mostly by Canadian interests) share directors with large corporations based elsewhere. Here, transnational interlocks have a quite different meaning. In 1996, 14 TNCs in the C250 had 31 transnational interlocks. By 2006, 22 TNCs carry 54 such interlocks (see Figure 4). In percentage terms, the shift from interiorizing to exteriorizing interlocks is substantial. In 1996, 31.5 per cent of all transnational interlocks were of the interiorizing type (involving foreign-controlled firms). By 2006 that proportion had fallen to 16.4 per cent. In 1996, 27.9 per cent of transnational interlocks were carried by Canadian TNCs; by 200649.1 per cent were. This is evidence that the transnational elite network follows in the grooves of transnational investments and expansion with effects going in both directions but trending recently in the direction of expansion from Canada.

There is, thus, a relation between transnationalization of capital and transnational interlocking - in both directions, inward and outward. The bidirectional relation points to a process of capitalist cross-penetration. But for large Canadian firms, the outward dynamic of Canada-based internationalization has recently been dominant, and the inward-moving relation is decreasingly US-centred and increasingly multinational in ownership. Figures 5 and 6 provide a visual representation of the exteriorizing interlocks that link Canadian TNCs to large corporations domiciled in other countries. The sociograms represent the social space at the seam between the Canadian national network and the global network, at two moments in time.

Figure 5 shows the network of 65 firms in 1996, made up of 40 Canadian TNCs (shown as squares) that interlock either with other Canadian TNCs or with non-Canadian members of our G500 (the latter shown as circles). The latter category numbers 25, including 18 US-based firms and seven firms based in Europe. The 14 Canadian TNCs with interlocks extending beyond the national border are shown as large black squares labeled with an abbreviation of the corporation's name; non-Canadian G500 members are also labeled, enabling one to trace all the interlocks that embed Canadian TNCs in the global corporate network. The leading character of each node label identifies the company's domicile. Line thickness indicates the number of directors that are shared by a pair of firms. The same graphical conventions apply to Figure 6, which shows, at yearend 2006, 42 Canadian TNCs and the 43 non-Canadian G500 companies that interlock with 22 of the Canadian TNCs. In both years, two of the Canadian TNCs in the network are foreign controlled. ${ }^{15}$

Because these sociograms were constructed using a spring-embedding algorithm, the relative distances between the points in each diagram approximate the distances in the actual network of corporations. At 1996, the network is clearly centred around 40 Canadian TNCs, which entirely occupy the core of the space and are extensively interconnected. Large corporations domiciled outside Canada surround this core, with eleven of the 18 US-based firms forming a single component to the south, and with all seven European firms also forming a

\footnotetext{
${ }^{15}$ In 1996 AMOCO Canada and Nexen were controlled in the US; in 2006 Inco was controlled in Brazil and Teck Corporation was (partially) controlled in Japan, with Sumitomo Metal Mining as a dominant shareholder, alongside the (Canadian) Keevil family.
} 
connected component to the east whose five French and Belgian companies (linked mainly to Montreal-based Seagram) share multiple directors.

Figure 5. Interlocks among Canandian TNCs and non-Canadian G500 firms, 1996

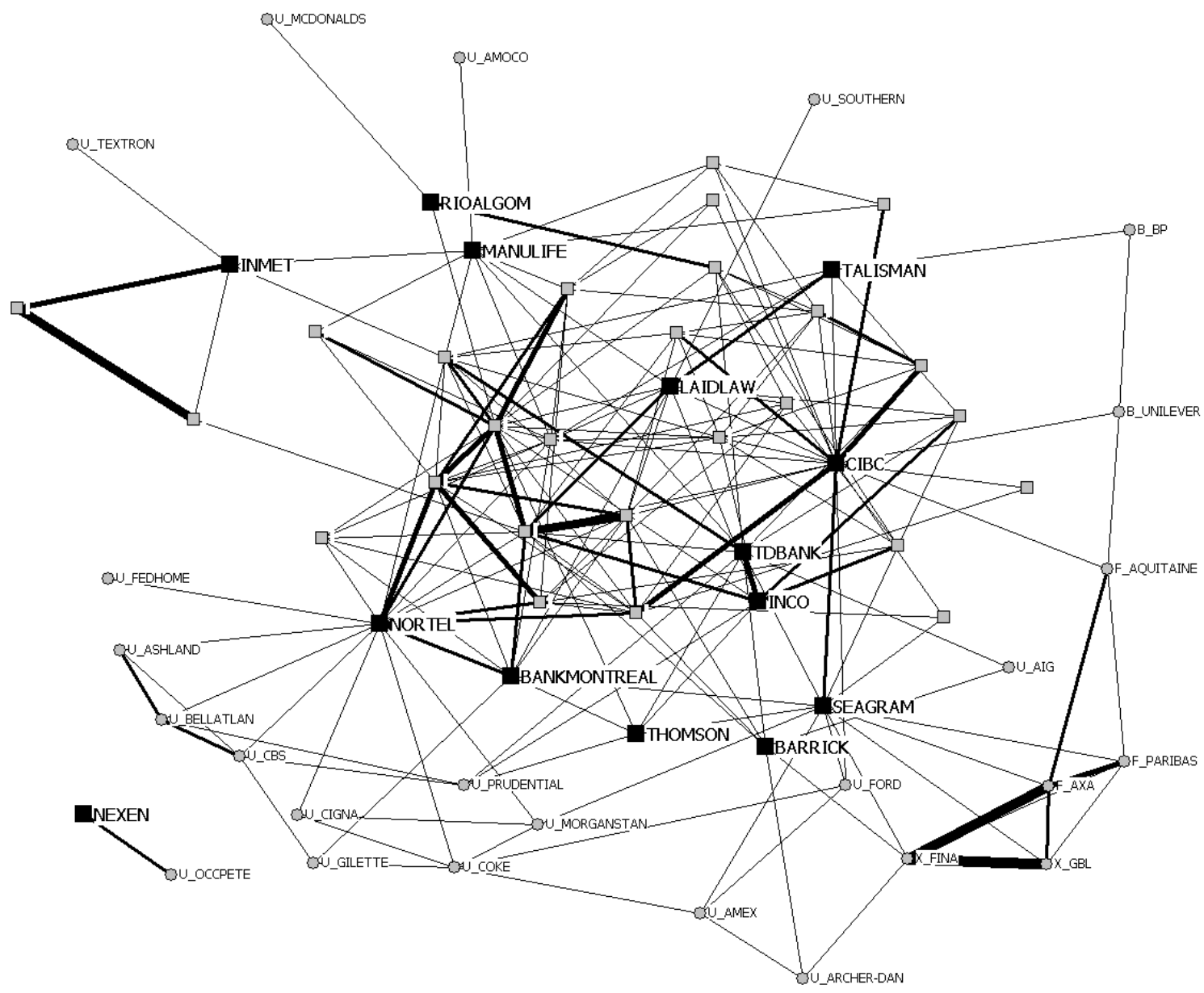

Key

Black squares: Canadian TNCs with transnational interlocks; grey squares: Canadian TNCs without transnational interlocks; grey circles: non-Canadian G500 members. Line thickness indicates the number of directors shared by a pair of firms. The leading character of each node label identifies each G500 company's domicile: ' $B$ ' - Britain; ' $F$ ' - France; ' $U$ ' - US; ' $X$ ' Belgium. 
Figure 6. Interlocks among Canandian TNCs and non-Canadian G500 firms, 2006

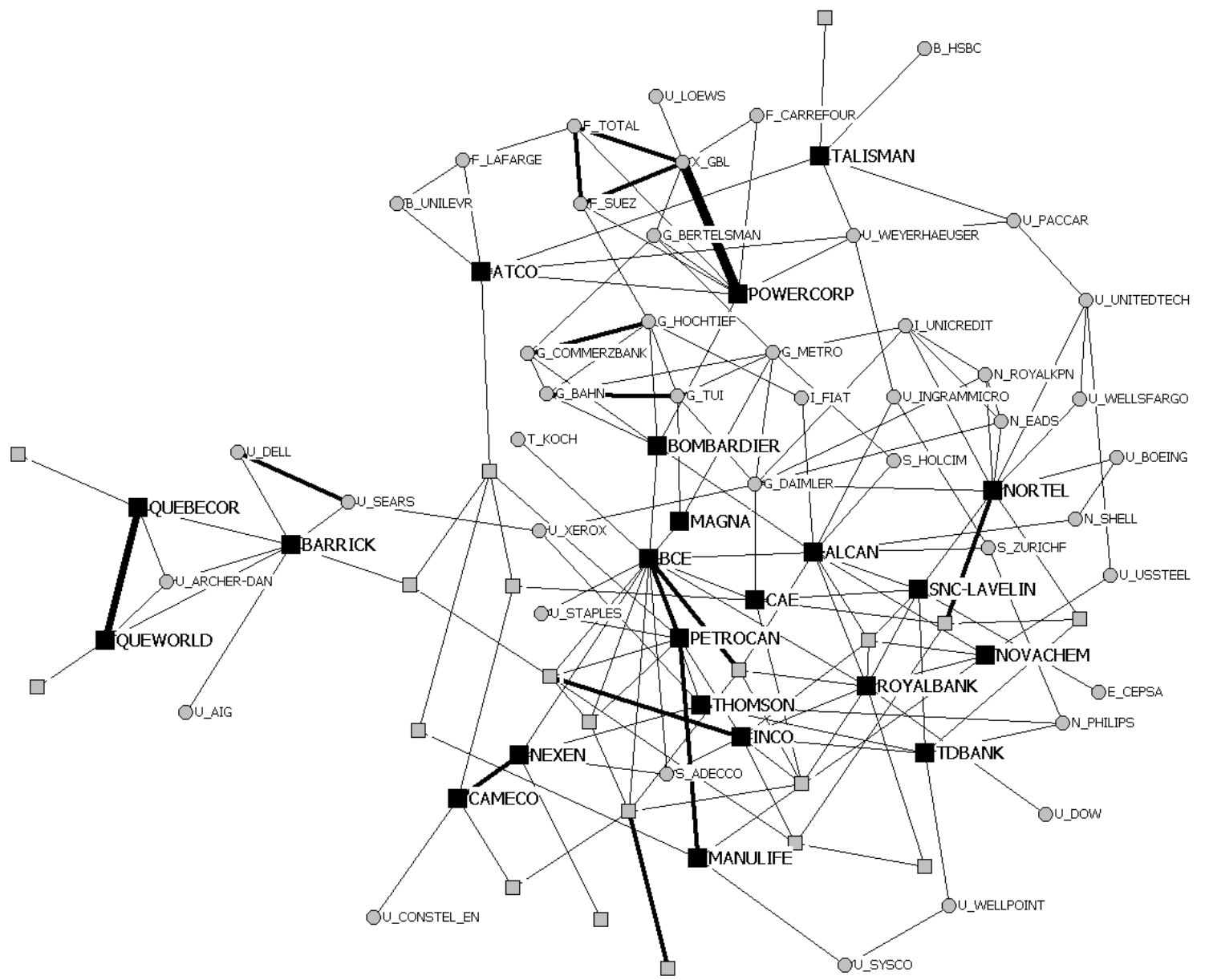

Key

Black squares: Canadian TNCs with transnational interlocks; grey squares: Canadian TNCs without transnational interlocks; grey circles: non-Canadian G500 members. Line thickness indicates the number of directors shared by a pair of firms. The leading character of each node label identifies each G500 company's domicile: 'B' - Britain; ' $E$ ' - Spain; 'F' - France; ' $G$ ' Germany; 'I' - Italy; ' $N$ ' - Netherlands; 'S' - Switzerland; ' $T$ ' - Turkey; ' $U$ ' - US; ' $X$ ' Belgium.

By 2006 the network is far less compactly centred upon Canadian TNCs: among the Canadian TNCs, density has fallen from 0.1872 to 0.0929 . Moreover, companies based in Europe now outnumber the 18 US-based firms that interlock with the Canadian TNCs; indeed, firms of varying domiciles intermingle in a more diffuse social space. The change is neatly summarized by considering the largest set of firms whose members each have $k$ or more ties to each other the kcore (Seidman 1983). In 1996, we find at the centre a 5-core of 28 firms, each interlocked 
with five or more other members of the 5-core - all of them domiciled in Canada. By 2006, the largest $k$ core is a 4-core of 18 firms. Not only is the kcore greatly diminished in size; its members are less profusely interlocked, and four of them are Europe-based (namely Daimler, UniCredit, Royal KPN and EADS), with Daimler playing an integrative role through its interlocks with Nortel, CAE, and the three other European companies. There is, at this seam between the Canadian network and the global network, not only a weakening in the centrality of Canadian TNCs, but a definite shift toward a European presence. Comparing the two sociograms, between 1996 and 2006 the total number of interlocks involving US-based firms drops from 52 to 42 while the number involving European companies rises from 29 to 89.

In both years, ties connecting Canadian TNCs and G500 firms domiciled elsewhere are 'thin' - carried by single directors - indicative not of control relations but of informal alignments that facilitate business scan (Useem 1984) and help to build a transnational corporate community (Carroll 2010). With one important exception, 'thick' ties, carried by multiple interlocked directors and often indicative of deeper capital relations (Carroll and Sapinski 2011), stay within national borders. The noteworthy exception, in 2006, links Montréal-based Power Corporation with Brussels-based Groupe Bruxelles Lambert, via four shared directors. This transnational interlock represents a key nexus for what Carroll (2009) describes as the only transnational financial empire of significance within the world's 500 leading corporations: an alliance of the Desmarais family of Montréal and the Frère family of Brussels, which controls a number of major corporations in Canada and Europe. ${ }^{16}$

To summarize, our data on directorship interlocks reveal that, over the past decade, a significant recomposition of the Canadian corporate community took place. This recomposition appears both within the $\mathrm{C} 250$ and between the firms of the C250 and the G500. First, the evidence demonstrates a less dense, yet relatively stable national network of directorship ties amongst C250 firms, which still interlock with each other at a greater scale than with G500 firms. Canadian-based transnationals come to play a more central role in the national network; nationally bound firms are relegated to its margins or detached from it entirely. The evidence also reveals that directors of foreign controlled firms became significantly less connected to the national network, and that by 2006 such interlocks represented a more diverse complement of cross-border ties, as ties with European subsidiaries increased vis-à-vis American ones. The implications of this finding are that the corporate network in Canada is largely dominated by nationally owned firms, in particular, by leading TNCs under Canadian ownership; and that a more geographically diverse - i.e. less 'continental' - network is emerging. Finally, the data indicate a growing set of directorship interlocks between Canadian-owned TNCs and the largest foreign-based firms in the world. These interlocks demonstrate primarily an 'exteriorization' of corporate power, and thus exhibit a new process of transnational class formation by Canadian firms as they expand operations beyond the US into Europe and other regions of the world economy.

\footnotetext{
${ }^{16}$ In 1996, Power Corporation of Canada was already networked across the Atlantic, but although its investments in and beyond Canada were substantial, it did not qualify as a TNC. See Carroll (2004: 64-5).
} 


\section{CONCLUSION}

We observe, then, complex transformations in the Canadian corporate network during the past decade of neoliberal globalization - transformations shedding light on new forms of transnationality in the corporate power bloc. On the one hand, we find a growing polarization within the C250, marked by the absolute decline and relative stagnation of nationally bound firms, and the rapid growth and international expansion of TNCs and near-TNCs. The evidence indicates a progressive concentration of capital within the TNCs of the C250, and a marked tendency for these firms to interlock more with each other than with sub-transnational firms. Within the C250, we also find that foreign control, though increasingly marginal, emanates almost entirely from the Triad and is most extensive among those with no foreign subsidiaries of their own - classic branch plants. Some of these firms are involved in transnational interlocking of the interiorizing sort, but they rarely participate in the Canadian corporate network. Instead, the national network is carried mostly by Canadian-owned firms, particularly TNCs and near-TNCs. For this reason, we concur with Robinson's (2004) assessment of TNCs as leading agents of capital accumulation, but note the persistence of a 'national corporate community' in Canada (Scott 1997) and the bifurcation of this community into TNCs and non-TNCs.

In addition, we observe a more transnational scope of investment by Canadian firms, which increasingly hold subsidiaries across the Triad, most importantly in the US and Europe. In this sense, Canadian firms in the C250 operate not as continental 'compradors' but as active members of an 'Atlantic ruling class', with transnational reach into both developed and developing countries (van der Pijl 1984). Over the decade, as the number of large Canadian TNCs grew, the national network became more focused upon them and their transnational interlocking expanded considerably, effecting a relative shift from interiorizing to exteriorizing interlocks.

As a result, the interface between capital accumulation and class formation broadly matches our scenario F, with several specifications:

i. transnational interlocking becomes weighted more toward the exteriorization of Canada-based capitalist interests and less toward interiorization of foreign-based corporate power;

ii. exteriorizing and interiorizing practices take in a widening range of foreign domiciles; and:

iii. the national network is increasingly centred upon the same Canadian TNCs that participate heavily in the transnational network.

In short, globalizing firms are increasingly dominant in the national network, and increasingly integrated with the transnational network of corporate power. Non-transnationals, particularly firms whose investments are restricted to the home market, come to participate less in the 'national' network, whose own center of gravity is increasingly transnational. The reasons for the growing marginality of nationally bound firms are not immediately apparent. It may be that, in an era of corporate governance practices favoring 'leaner meaner' boards and fewer directorships per director, diminishing opportunities for interlocking promote a clustering of elite affiliations among the big, transnational players that shuts out many of the sub-transnationals, thereby amplifying the network's core-periphery structure. 
One trend worth highlighting is the elevated presence of Canadian TNCs in Europe, and the increased presence of European TNCs, through their subsidiaries, in Canada. As we saw, the elite network of directorship interlocks follows these trends in capital accumulation, in particular, through greater network connections between European and Canadian firms. In this regard, it is worth speculating that current moves towards a Canada-European Union free trade agreement stem in part from closer integration of capital, and capitalist classes, between these countries/regions.

Regardless, in the case of Canada, we observe an emerging relation between transnationalization of capital and transnational interlocking - in both directions, inward and outward. The two-way relation signals a process of capitalist cross-penetration, as TNCs based in Canada and around the world place investments in each other's national domains while also exporting capital to developing countries (Portes and Walton 1981: 142; Carroll and Klassen 2010: 23). For Canadian TNCs, however, the outward dynamic of internationalization has recently been dominant, while the inward dynamic is decreasingly US-centred and increasingly multinational in scope. The trend is dialectical: Canadian TNCs have reinforced a national network of corporate power and simultaneously interlocked with foreign-based TNCs both inside and outside of Canada, in the grooves formed by transnational investment. The trajectory of Canada's corporate community exemplifies Sassen's maxim: "the global partly inhabits and partly arises out of the national" (2007: 1). Sassen goes on to note that the global/national nexus troubles two core propositions in modern social science: (1) that the nation-state is the container of political, economic and social processes; and (2) that the global and the national are two mutually exclusive entities. Our case study of Canada underlines the importance, in an era of global capitalism, of analyzing the national and the transnational as mutually constitutive elements in processes of class formation. Further comparative research could consider the conditions under which interiorizing and exteriorizing processes come to predominate at specific national sites within the world system, and the ramifications for corporate communities at national and transnational levels.

In conclusion, we find definite relations between investment and interlocking that shape the social space of national corporate communities and the global corporate elite. Corporations with a transnational accumulation base tend to participate in transnational interlocking. Successful capital accumulation and corporate interlocking appear as mutually reinforcing processes, as transnational firms increasingly network within their 'home' domiciles and with others emanating from the Triad. While national corporate communities have not been transcended, they are increasingly inhabited by transnational firms, which articulate with other TNCs on a global scale. These corporations constitute the leading edge of capital accumulation and, through their dense network of cross-border investments and interlocking directorates, form the rudiments of a transnational capitalist class.

\section{ACKNOWLEDGEMENTS}

This research was supported by grants from the Social Sciences and Humanities Research Council of Canada. 


\section{REFERENCES}

Arthurs, Harry W. 2000. "The hollowing out of corporate Canada?" Pp. 29-51 in Globalizing Institutions: Case Studies in Regulation and Innovation, edited by J. Jenson and B. de Sousa Santos. Burlington, VT: Ashgate Publishing Company.

Bello, Walden. 2006. "The capitalist conjuncture: over-accumulation, financial crises, and the retreat from globalization." Third World Quarterly 27(8): 1345-67.

Brownlee, Jamie. 2005. Ruling Canada: Corporate Cohesion and Democracy. Halifax: Fernwood.

Burgess, William. 2000. "Foreign direct investment: facts and perceptions about Canada." The Canadian Geographer 44(2): 98-113.

Carroll, W. K. 1986. Corporate Power and Canadian Capitalism. Vancouver: University of British Columbia Press. . 2004. Corporate Power in a Globalizing World. Toronto: Oxford University Press. . 2008. "The corporate elite and the transformation of finance capital: a view from Canada." Sociological Review 56(S1): 44-63. . 2009. "Transnationalists and national networkers in the global corporate elite." Global Networks 9(3): 289-314. . 2010. The Making of a Transnational Capitalist Class. London: Zed Books.

Carroll, W. K. and Jerome Klassen. 2010. "Hollowing out corporate Canada? Changes in the corporate network since the 1990s." Canadian Journal of Sociology 35(1): 1-30.

Carroll, W.K. and J.P. Sapinski. 2011. "Corporate elites and intercorporate networks." Pp. 180-95 in Handbook of Social Network Analysis, edited by J. Scott and P. Carrington. London: Sage.

Clement, Wallace. 1975. The Canadian Corporate Elite: An Economic Analysis of Power. Toronto: McClelland and Stewart Limited.

Clement, Wallace. 1977. Continental Corporate Power: Economic Linkages Between Canada and the United States. Toronto: McClelland and Stewart Limited.

Desai, Radhika. 2007. "The last empire? From nation-building compulsion to nation-wrecking futility and beyond." Third World Quarterly 28(2): 435-56.

Domhoff, G. William. 2006. Who Rules America? Power, Politics \& Social Change (5 ${ }^{\text {th }}$ ed.). New York. McGraw-Hill.

Fennema, Meindert and Huibert Schijf. 1985. "The transnational network." Pp. 250-66 in Networks of Corporate Power, edited by F. N. Stokman, R. Ziegler and J. Scott. Cambridge: Polity Press.

Gill, Stephen. 2003. Power and Resistance in the New World Order. New York: Palgrave.

Hardt, Michael and Antonio Negri. 2000. Empire. Cambridge, MA: Harvard University Press.

Harris, Jerry. 2005. "To be or not to be: The nation-centric world order under globalization." Science \& Society 69(3): 329-40.

Heemskerk, Eelke M. 2007. Decline of the Corporate Community: Network Dynamics of the Dutch Business Elite. Amsterdam: Amsterdam University Press.

Kentor, Jeffrey. 2005. "The growth of transnational corporate networks: 1962-1998." Journal of World-Systems Research 11(2): 263-86. 
Kentor, Jeffrey and Y.S. Jang. 2004. "Yes, there is a (growing) transnational business community: a study of global interlocking directorates 1983-98." International Sociology 19(3): 355-68.

Klassen, Jerome. 2009. "Canada and the New Imperialism." Studies in Political Economy 83 (Spring): 163-90.

Levitt, Kari. 1970. Silent Surrender: The Multinational Corporation in Canada. Toronto: MacMillan of Canada.

Moore, J. W. 2002. "Capital, territory, and hegemony over the longue duree." Science \& Society 65(4): 476-84.

Neubauer, Fred, Ulrich Steger and Georg Radler. 2000. "The Daimler/Chrysler merger: the involvement of the boards." Corporate Governance 8(4): 375-87.

Naylor, R.T. 1972. "The rise and fall of the Third Commercial Empire of the St. Lawrence." Pp. 1-41 in Capitalism and the National Question in Canada, edited by G. Teeple. Toronto: University of Toronto Press.

Niosi, Jorge. 1985. Canadian Multinationals. Toronto: Garamond Press.

Organisation for Economic Cooperation and Development. 2008. OECD Factbook 2008. Retrieved from Source OECD Online (http://www.sourceoecd.org/factbook/).

Panitch, Leo and Sam Gindin. 2004. "Global Capitalism and American Empire." Pp. 1-43 in The Socialist Register 2004: The New Imperial Challenge, edited by L. Panitch and C. Leys. London: Merlin.

. 2005. "Finance and American Empire." Pp. 46-81 in The Socialist Register 2005: The Empire Reloaded, edited by L. Panitch and C. Leys. London: Merlin.

Portes, Alejandro and John Walton. 1981. Labor, Class, and the International System. Toronto: Academic Press.

Poulantzas, Nicos. 1978. Classes in Contemporary Capitalism. London: Verso.

Richardson, Jack. 1982. “"Merchants against industry': An empirical study of the Canadian debate." Canadian Journal of Sociology 7(3): 279-96. . 1988. "A Sacred Trust": The trust industry and Canadian economic structure." Canadian Review of Sociology and Anthropology 25(1): 1-19.

Robinson, William I. 2004. A Theory of Global Capitalism: Production, Class, and State in a Transnational World. Baltimore: John Hopkins University Press.

Sassen, Saskia. 2007. "Introduction: Deciphering the global." In Deciphering the Global: Its Scales, Spaces and Subjects, edited by S. Sassen. New York: Routledge.

Scott, John. 1997. Corporate Business and Capitalist Classes. Oxford: Oxford University Press.

Seidman, Stephen. 1983. "Network structure and minimum degree." Social Networks 5(3): 26987.

Sklair, Lesley. 2001. The Transnational Capitalist Class. Oxford: Blackwell Publishers.

United Nations Conference on Trade and Development. 2009. World Investment Report 2008. New York and Geneva: United Nations.

Useem, Michael. 1984. The Inner Circle: Large Corporation and the Rise of Business Political Activity in the U.S. and U.K. New York: Oxford University Press.

van der Pijl, Kees. 1984. The Making of an Atlantic Ruling Class. London: Verso. . 2005. "A theory of global capitalism, feature review." New Political Economy 10(2): 273-7. 